\title{
Antimalaria Activities of Several Active Compounds from Medicinal Plants
}

\author{
Maulana Yusuf Alkandahri ${ }^{1,2, *}$, Nia Yuniarsih ${ }^{2}$, Afiat Berbudi ${ }^{3}$, Anas Subarnas $^{1}$
}

\section{Maulana Yusuf Alkandahri, ${ }^{1,2 *}$, Nia Yuniarsih ${ }^{2}$, Afiat Berbudi ${ }^{3}$, Anas Subarnas ${ }^{1}$}

'Department of Pharmacology and Clinical Pharmacy, Faculty of Pharmacy, Padjadjaran University, Jatinangor, West Java, INDONESIA.

${ }^{2}$ Faculty of Pharmacy, Buana Perjuangan Karawang University, Karawang, West Java, INDONESIA.

${ }^{3}$ Department of Biomedical Sciences, Parasitology Division, Faculty of Medicine, Padjadjaran University, Bandung, West Java, INDONESIA.

\section{Correspondence}

\section{Maulana Yusuf Alkandahri}

Department of Pharmacology and Clinical Pharmacy, Faculty of Pharmacy, Padjadjaran University, Jatinangor; Faculty of Pharmacy, Buana Perjuangan Karawang University, Karawang, West Java, INDONESIA.

Phone no: +6282167757738

E-mail: alkandahri@gmail.com

History

- Submission Date: 04-11-2021;

- Review completed: 02-12-2021;

- Accepted Date: 07-12-2021.

DOI : $10.5530 /$ pj.2022.14.30

Article Available online http://www.phcogj.com/v14/i1

Copyright

(c) 2022 Phcogj.Com. This is an openaccess article distributed under the term of the Creative Commons Attribution 4.0 International license.

\section{ABSTRACT}

The growth and spread of resistance to all first-line antimalarial drugs used in the treatment of malaria today has caused many problems in eradicating malaria in various countries in the world. Researchers have begun to look for candidates for new antimalarial drug compounds derived from natural products that have been scientifically proven to have antimalarial activity. This is done to replace antimalarial drugs that are currently experiencing resistance. Some active compounds that have been successfully isolated from various plants, including curcumin, kaempferol, piperine, andrographolide, a-mangostin, catechin, luteolin and betulinic acid, have been scientifically tested to have antimalarial activity with different mechanisms of action.

Key words: Malaria, Antimalarial, Curcumin, Kaempferol, Piperine, Andrographolide, a-Mangostin, Catechin, Luteolin, Betulinic acid.

\section{INTRODUCTION}

Malaria is still a health problem in the world, with 229 million cases of malaria worldwide and more than 400,000 people suffering from malaria dying each year. ${ }^{1}$ The high number of malaria cases is caused by the emergence of various obstacles in eradicating malaria, including the resistance of malaria parasites to available antimalarial drugs, increased Anopheles mosquito immunity to chemicals, and the discovery of side effects from these antimalarial drugs. ${ }^{2}$ The growing and widespread resistance to all the first-line antimalarial drugs used in the treatment and prevention of malaria has now caused many problems in the malaria prevention programme. ${ }^{3}$ Research to obtain new antimalarial drugs, both synthetic drugs and those derived from natural materials, is continuing, one of which is through the exploration of active compounds from natural materials, especially medicinal plants that have traditionally been used by the community to treat malaria in various endemic areas across the world. The aim is to find new antimalarial compounds that have mild side effects with low toxicity, so that they do not harm the patient. ${ }^{4}$ This review article will discuss the active compounds and antimalarial activity of several medicinal plant isolates.

\section{CURCUMIN}

Curcumin (1,7-bis (4'hydroxy-3-methoxyphenyl) 1,6-heptadiene, 3,5-dion) is a phytochemical component found mainly in Curcuma longa and Curcuma zanthorrhiza. Curcumin is often used as a medicine and traditional ingredient to treat various diseases in several countries. ${ }^{5}$ Curcumin has several pharmacological activities such as anti-inflammatory, ${ }^{6-7}$ antioxidant, ${ }^{8}$ anticancer, ${ }^{9}$ anticoagulant, ${ }^{10}$ hepatoprotective ${ }^{11}$ and antibacterial. ${ }^{12}$ In addition, curcumin has been shown to have antimalarial activity against Plasmodium species. ${ }^{13-14}$ The antimalarial activity of curcumin is caused by its ability to inhibit histone acetyltransferase from $P$. falciparum, causing parasitic cell damage. ${ }^{14}$ Other studies also report that curcumin can interact with sarco/endoplasmic reticulum $\mathrm{Ca}^{2+}$ ATPase (SERCA) in $P$. falciparum which causes the inhibition of a $\mathrm{Ca}^{2+}$ ion transporter called PfATP6. ${ }^{15}$ Meanwhile, from in vitro antimalarial activity testing, $\mathrm{IC}_{50}$ values obtained from curcumin were $5 \mu \mathrm{M}$, whereas at concentrations of $50 \mu \mathrm{M}$, curcumin was able to reduce the viability of $P$. falciparum, which caused a decrease in parasitic cell proliferation. Other results also reported that at concentrations of $5 \mu \mathrm{g} / \mathrm{ml}$ and $50 \mu \mathrm{g} / \mathrm{ml}$, curcumin was able to inhibit $79.6 \%$ and $100 \%$ growth of $P$. falciparum. ${ }^{16}$ In addition, in antimalarial testing in vivo with a dose of $100 \mathrm{mg} / \mathrm{kg}$, curcumin was able to inhibit the growth of parasites $>80 \% .{ }^{13}$ WaknineGrinberg et al. reported that the administration of curcumin at a dose of $50 \mathrm{mg} / \mathrm{kg}$, twice daily for 6 days after infection in C57Bl/6 mice infected with $P$. berghei ANKA, can prevent cerebral malaria (CM) and delay death by up to 10 days. ${ }^{17}$ In addition, it has been shown in vitro that curcumin reduces the production of proinflammatory cytokines IL6, TNF and IL12p40 in PBMC primed with trophozoites/ schizonts stages of $P$. falciparum and downregulated the expression of VCAM1, ICAM1 and E-selectin in TNF-activated human endothelial cells. ${ }^{18}$ In addition, other studies report that curcumin can inhibit thrombin-activated platelet adhesion to brain microvascular endothelial cells in vitro ${ }^{19}$ which is thought to accumulate in brain microvasculature in murine and pediatric CM patients..$^{20}$

\section{KAEMPFEROL}

Kaempferol (3,4'5, 5,7-tetrahydroxyflavone) is a natural flavonol, a flavonoid derivative, found in various plants and plant-derived foods such as kale, beans, tea, spinach and broccoli. ${ }^{21-22}$ Kaempferol has been reported to have high antioxidant properties, which are able to inhibit oxidative stress resulting from the formation of reactive oxygen species (ROS) 
that occur during malaria infections. ${ }^{23}$ ROS and oxidative stress are also produced by monocytes and neutrophils which are activated during malarial infection, which cause haemoglobin to degrade, ${ }^{24-25}$ thus there is a correlation between antioxidant activity and antimalarial activity of kaempferol. ${ }^{26}$ In addition, the antimalarial activity of kaempferol is also caused by its ability to inhibit glycogen synthase kinase-3 $\beta$ (GSK3 $\beta$ ) from malaria parasites. GSK $3 \beta$ is reported to play an important role in the host response to malaria parasitic infections. ${ }^{27-28}$ By inhibiting GSK3 $\beta$ in mammals, it can also significantly inhibit the activity of recombinant P. falciparum (PfGSK3 $\beta$ ) protein. ${ }^{29}$ Somsak et al., reported that at a dose of $20 \mathrm{mg} / \mathrm{kg}$, kaempferol was able to inhibit $P$. berghei by $52.89 \%, 40.80 \%$, and $36.63 \%$ for each chemosuppressive, chemoprophylactic, and curative trial. ${ }^{30}$ Meanwhile, Barliana et al., reported that kaempferol was able to inhibit the growth of $P$. falciparum which is resistant to chloroquine in vitro after 24 hours of therapy with $\mathrm{IC}_{50} 106 \mu \mathrm{M} .{ }^{31}$ In addition, kaempferol at a dose of $2,000 \mathrm{mg} / \mathrm{kg}$ daily for 30 days does not produce signs of toxicity in the form of hepatotoxic, nephrotoxic, haematotoxic, or death in test animals. ${ }^{30}$

\section{PIPERINE}

Piperine (1-[5-(1,3-benzodioxol-5-yl)-1-oxo-2,4-pentadienyl] piperidine) is the main amide compound isolated from the Piper chaba Hunt fruit, ${ }^{32}$ Piper nigrum L. (black pepper) and Piper longum L. (long pepper). ${ }^{33}$ Piperine has been shown to have several pharmacological activities such as antioxidants, ${ }^{34}$ anticancer, ${ }^{35}$ antidepressive, ${ }^{36}$ hepatoprotective, ${ }^{37}$ anti-asthmatic, ${ }^{38}$ antipyretic, ${ }^{33}$ anti-inflammatory, ${ }^{39}$ analgesic, and anticonvulsant. ${ }^{40}$ In addition, piperine was also reported to have antimalarial activity in vitro against P.falciparum 3D7 strains (chloroquine-sensitive) and $\mathrm{K} 1$ (chloroquine-resistant) with $\mathrm{IC}_{50}$ against $3 \mathrm{D} 7$ and $\mathrm{K} 1$ P.falciparum respectively at $111.5 \mu \mathrm{M}$ and $59 \mu \mathrm{M} .^{32}$ The antimalarial activity of piperine is due to its ability to inhibit the modulation of expression of all P. falciparum resistance genes, ${ }^{32}$ including the $P$. falciparum multidrug resistance protein 1 gene ( $p f m r p 1$ ), the $p f m r p 1$ protein coding gene that is a member of the $\mathrm{ABC}$ transporter superfamily located on chromosome $1,{ }^{41}$ where this protein has been reported to be involved in the export of folate from malaria parasites into red blood cells, ${ }^{42} \mathrm{P}$. falciparum multidrug resistance gene 1 ( $p f m d r 1$ ) is a homologous $\mathrm{P}$-glycoprotein coding gene located in the parasite digestive vacuole membrane, which is thought to play a role in modulation of antimalarial drug resistance ${ }^{43}$ and $P$. falciparum chloroquine resistance transporter $(p f c r t)$, a protein-coding gene that is localised to the parasitic digestive vacuole membrane and contains 10 domains that line the membrane in the erythrocytic stage. ${ }^{44}$ Piperine might be a promising candidate for the development of new antimalarial drugs, due to its antimalarial potential and low risk of resistance in modulating the $P$. falciparum resistance gene that causes the development of resistance. ${ }^{32}$

\section{ANDROGRAPHOLIDE}

Andrographolide (3-[2-[Decahydro-6-hydroxy-5-(hydroxymethyl)5,8a-dimethyl-2-methylene-1-napthalenyl]ethylidene] dihydro-4hydroxy-2(3H)-furanone) is a lactone diterpene compound isolated from the Andrographis paniculata (Burm. F) Nees plant, commonly known as the "king of bitters". ${ }^{45}$ Andrographolide has been reported to have several pharmacological activities such as anti-inflammatory, antitumor, antidiabetic, and hepatoprotective. ${ }^{46}$ In addition, andrographolide has been shown to have antimalarial activity in vitro and in vivo. ${ }^{47}$ The antimalarial activity of andrographolide is due to its ability to inhibit nuclear kappa $\mathrm{B}(\mathrm{NF}-\kappa \mathrm{B})$ transcription factors induced when erythrocytes are infected with $P$. falciparum ${ }^{48}$ by blocking the binding of NF- $\kappa \mathrm{B}$ oligonucleotides to nuclear proteins ${ }^{49}$ where this pathway is an inflammatory pathway in the human cerebral

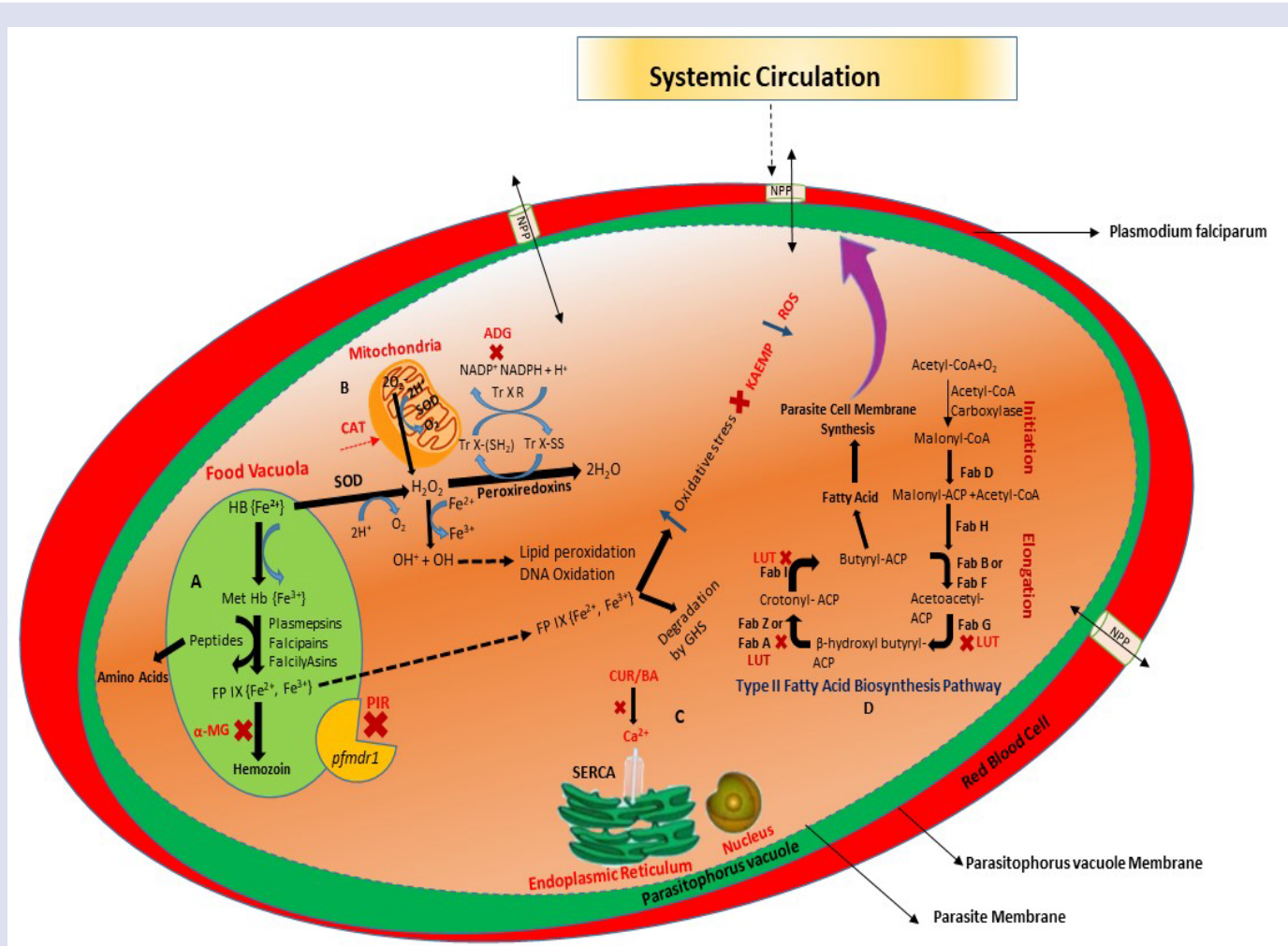

Figure 1. Parasite targets for intervention. A) Heme detoxification pathways in the intra-erythrocytic cycle and redox homeostasis in infected red blood cell: a-mangostin inhibit heme degradation in the parasite food vacuole. B) The electron transport chain (ETC) of mitochondria involve in the bio-activation of catechin induces the membrane depolarization and disrupt the normal function of mitochondria, through the production of ROS. Furthermore, andrographolide inhibits thioredoxin reductase an enzyme maintains the redox equilibrium in plasmodium species. C) Inactivation of SERCA which is responsible for protein synthesis in parasite by curcumin and betulinic acid. D) Inhibition of type II fatty acid biosynthesis pathway in $P$. falciparum by luteolin. 
Table 1. Active compounds and working mechanisms as antimalaria.

\begin{tabular}{|c|c|c|c|c|c|}
\hline Active Compounds & Chemical Structures & Types of Malaria Parasites & Study Design & Mechanism of Action & References \\
\hline Curcumin & $\begin{array}{l}\mathrm{C}^{\prime} \mathrm{CH}_{3} \\
\end{array}$ & $\begin{array}{l}\text { 1. } P \text {. falciparum strain } 3 \mathrm{D} 7 \text { and } \mathrm{D} 10 \text {. } \\
\text { 2. } P \text {. falciparum strain } \mathrm{DD} 2 \text { and } 7 \mathrm{G} 8 \text {. } \\
\text { 3. P. berghei strain ANKA. }\end{array}$ & $\begin{array}{l}\text { In vitro and in } \\
\text { vivo }\end{array}$ & $\begin{array}{l}\text { Interacts with sarco/ } \\
\text { endoplasmic reticulum } \\
\mathrm{Ca}^{2+} \text { ATPase (SERCA) in } \\
\text { P. falciparum which causes } \\
\text { inhibition of } \mathrm{Ca}^{2+} \text { ion } \\
\text { transporter. }\end{array}$ & 15 \\
\hline Kaempferol & & $\begin{array}{l}\text { 1. P. falciparum strain 3D7. } \\
\text { 2. P. berghei strain ANKA. }\end{array}$ & $\begin{array}{l}\text { In vitro and in } \\
\text { vivo }\end{array}$ & $\begin{array}{l}\text { Inhibits oxidative stress } \\
\text { resulting from the formation } \\
\text { of reactive oxygen species } \\
\text { (ROS). }\end{array}$ & 23 \\
\hline Piperine & & $\begin{array}{l}\text { 1. P. falciparum strain } 3 \mathrm{D} 7 \text {. } \\
\text { 2. P. falciparum strain } \mathrm{K} 1 \text {. }\end{array}$ & In vitro & $\begin{array}{l}\text { Inhibits the modulation of } \\
\text { expression of all } P \text {. falciparum } \\
\text { resistance genes. }\end{array}$ & 32 \\
\hline Andrographolide & & $\begin{array}{l}\text { 1. P. falciparum strain } 3 \mathrm{D} 7 \text {. } \\
\text { 2. P. berghei strain ANKA. }\end{array}$ & $\begin{array}{l}\text { In vitro and in } \\
\text { vivo }\end{array}$ & $\begin{array}{l}\text { Reduction in GSH } \\
\text { concentration and the activity } \\
\text { of the thioredoxin reductase } \\
\text { (TrxR) enzyme. }\end{array}$ & 50 \\
\hline a-Mangostin & & $\begin{array}{l}\text { 1. P. falciparum strain K1. } \\
\text { 2. P. falciparum strain FCR3. } \\
\text { 3. P. falciparum strain 3D7. } \\
\text { 3. P. berghei strain ANKA. }\end{array}$ & $\begin{array}{l}\text { In vitro and in } \\
\text { vivo }\end{array}$ & $\begin{array}{l}\text { Inhibits haemoglobin } \\
\text { degradation process that } \\
\text { occurs in the food vacuole of } \\
\text { P. falciparum. }\end{array}$ & $53,58,59$ \\
\hline Catechin & & $\begin{array}{l}\text { 1. P. falciparum strain DD2. } \\
\text { 2. P. falciparum strain 3D7. }\end{array}$ & In vitro & $\begin{array}{l}\text { Induces oxidative stress to } P \text {. } \\
\text { falciparum. }\end{array}$ & 62,63 \\
\hline Luteolin & & $\begin{array}{l}\text { 1. P. falciparum strain 3D7. } \\
\text { 2. P. falciparum strain } 7 \mathrm{G} 8 \text {. }\end{array}$ & In vitro & $\begin{array}{l}\text { Inhibits FabG, FabZ and } \\
\text { FabI enzymes which } \\
\text { involves in parasite fatty acid } \\
\text { biosynthesis. }\end{array}$ & 69 \\
\hline Betulinic acid & & $\begin{array}{l}\text { 1. P. falciparum strain } \mathrm{K} 1 . \\
\text { 2. P. falciparum strain T9-96. } \\
\text { 3. P. falciparum strain } 3 \mathrm{D} 7 \text {. }\end{array}$ & In vitro & $\begin{array}{l}\text { Ability to bind the } \\
\text { PfATP6 protein and sarco/ } \\
\text { endoplasmic reticulum } \\
\mathrm{Ca}^{2+} \text { ATPase (SERCA) in } \\
\text { mammals. }\end{array}$ & $75-77$ \\
\hline
\end{tabular}

endothelium..$^{47-48}$ Meanwhile, Risdawati reported that the antimalarial andrographolide activity was caused by this compound being able to disrupt the parasitic antioxidant defence system as evidenced by the reduction in GSH concentration and the activity of the thioredoxin reductase (TrxR) enzyme. ${ }^{50}$ Kusumawardhani, et al., reported that the antimalarial activity of standardised $A$. paniculata leaf extracts (andrographolide levels; $10.82 \pm 0.37 \%$ ) against $P$. berghei in vivo obtained $\mathrm{ED}_{50}$ of $12.2223 \mathrm{mg}$ of standardised A. paniculata /KgBW leaf extract, equivalent to $1,320 \mathrm{mg}$ of andrographolide compounds. ${ }^{51}$ Meanwhile, Sachdeva reported that andrographolide at a dose of 0.1 $\mathrm{mg} / \mathrm{ml}$ was able to inhibit the growth of malaria parasites in vitro by $53.9 \% .^{52}$ In addition, Mishra et al., reported that andrographolide showed high malaria parasitic inhibitory activity in rat models in vivo when given with curcumin or artesunate via the intraperitoneal route, and without showing any symptoms of toxicity after administration of the therapy. ${ }^{47}$

\section{a-MANGOSTIN}

a-mangostin (1,3,6-trihidroksi-7-metoksi-2,8-bis (3metil-2-butenil)9H-xanten-9-on) is the main xanthone compound found in the hull of the Garcinia mangostana L fruit..$^{33}$ This compound has been reported to have pharmacological activities including anti-inflammatory, anti-tumor, cardioprotective, antidiabetic, antibacterial, antifungal, antiparasitic, antioxidant and anti-obesity agents. ${ }^{54}$ In addition, a-mangostin is also reported to have antimalarial activity. ${ }^{53}$ Antimalarial activity is suspected of $\alpha$-mangostin which is a hydroxyxanthones derivative due to its ability to form complexes that are soluble with heme compounds so that it inhibits the formation of parasitic hemozoin, a process in which the malaria parasite protects itself against the effects of heme toxins released after digesting haemoglobin. ${ }^{55-56}$ The effect was caused by this compound having an alkyl group located in positions 3 and 6 which interacts with nitrogen atoms contained in 
heme propionate compounds thus forming ionic bonds which cause an increase in antiplasmodial activity. ${ }^{56-57}$ This is in accordance with the research of Kuncoro, et al., which reported that with a-mangostin able to inhibit the development of trophozoite stages into schizon stages in P. falciparum, where at the trophozoite stage an increase in haemoglobin uptake, with inhibition of haemoglobin uptake, would result in inhibition haemoglobin degradation process that occurs in the food vacuole of $P$. falciparum. ${ }^{58}$ Mahabusarakam et al., reported that active $\alpha$-mangostin inhibits the growth of $P$. falciparum strain $\mathrm{K} 1$ (chloroquine and pyrimethamine-resistant) in vitro with $\mathrm{IC}_{50}$ of 17 $\mu \mathrm{M} .{ }^{53}$ This is in accordance with the results of research by Upegui et al., who reported that $\alpha$-mangostin was more active in inhibiting the growth of $P$. falciparum strain FCR3 (chloroquine-resistant) in vitro with $\mathrm{IC}_{50}$ of $0.2 \pm 0.01 \mu \mathrm{M}$ compared to $\delta$-mangostin with $\mathrm{IC}_{50}$ is 121.2 $\pm 1.0 \mu \mathrm{M}$, but $\delta$-mangostin is more active in inhibiting the growth of P. falciparum strain 3D7 (chloroquine-sensitive) in vitro with $\mathrm{IC}_{50}$ of $12.40 \pm 1.0 \mu \mathrm{M}$ compared to $\alpha$-mangostin with $\mathrm{IC}_{50}$ of $36.10 \pm 4.9 \mu \mathrm{M} .^{59}$ In addition, Upegui et al., also reported that at doses of $100 \mathrm{mg} / \mathrm{kg} /$ day twice daily for 7 days, $\alpha$-mangostin and $\delta$-mangostin were able to reduce the growth of $P$. berghei respectively by $80.7 \%$ and $79.9 \%{ }^{59}$ These findings can provide a basis for further research on $\alpha$-mangostin as a potential compound to be developed into antimalarial drugs. ${ }^{59}$

\section{CATECHIN}

Catechin (2R,3S)-2-(3,4-dihydroxyphenyl)-3,4-dihydro-2H-chromene3,5,7-triol) is the main bioactive compound found in green tea (Camellia sinensis). ${ }^{60}$ Catechin is reported to have several pharmacological activities including antioxidant, anti-microbial, anti-inflammatory, anti-viral, anti-cancer and anti-allergic properties. ${ }^{61}$ In addition, this compound is also reported to have antimalarial activity against $P$. falciparum. ${ }^{62-63}$ The antimalarial activity of catechin is due to its ability to induce oxidative stress to P. falciparum. ${ }^{63}$ Goyal et al., reported that Plasmodium is very susceptible to oxidative stress, where an increase in oxidative stress will cause a redox imbalance. ${ }^{64}$ Meanwhile, the redox system plays an important role in the survival of Plasmodium in the host cell, by disturbing the redox balance will affect the survival of Plasmodium during the intraerythrocytic stage. ${ }^{65}$ Budiman et al., reported that active catechin inhibited the growth of $P$. falciparum with $\mathrm{IC}_{50}$ of $0.734 \mu \mathrm{M},{ }^{62}$ this is in accordance with the research of Abdulah et al., who reported that catechin could inhibit the growth of $P$. falciparum strain DD2 (chloroquine-resistant) with $\mathrm{IC}_{50} 198 \mu \mathrm{M}$ after 24 hours of treatment. ${ }^{63}$ Although this is a preliminary study, the results of this study can provide information for further research on catechin as a potential compound as an antimalarial drug. ${ }^{63}$

\section{LUTEOLIN}

Luteolin $\left(3^{\prime}, 4^{\prime}, 5,7\right.$-tetrahydroxyflavone $)$ is a common flavonoid that exists in many types of plants, including herbs, vegetables and medicinal plants. ${ }^{66}$ Luteolin is reported to have several pharmacological activities including anti-inflammatory, antioxidant, antidiabetic, antimicrobial, and anticancer. ${ }^{67}$ In addition, luteolin was also reported to have antimalarial activity against $P$. falciparum strain 3D7 (chloroquinesensitive) and $P$. falciparum strain 7G8 (chloroquine-resistant) with IC $_{50}$ of $11 \pm 1 \mu \mathrm{M}$ and $12 \pm 1 \mu \mathrm{M}$, respectively. ${ }^{68}$ The antimalarial activity of luteolin is due to its ability to inhibit the development of parasitic growth at the stage of young trophozoites, so the parasite cannot complete the full intraerythrocytic cycle. ${ }^{68}$ This compound is also reported to Inhibits FabG, FabZ and FabI enzymes which are involved in parasite fatty acid biosynthesis. ${ }^{69}$ In vitro experiments show that luteolin can inhibit the activation of the nuclear factor kappa $B$ (NF-kB) induced by lipopolysaccharide (LPS) and members of the family of mitogen-activated protein kinase (MAPK) ERK, p38, and JNK. ${ }^{70-71} \mathrm{NF}-\kappa \mathrm{B}$ and MAPK are the two main pathways involved in the activation of macrophages in epithelial cells and stromal tissue in response to inflammatory mediators such as TNFa and ILs. ${ }^{72}$ It is also an inflammatory pathway in the human cerebral endothelium. ${ }^{47-48}$ The results of these studies can make the initial hypothesis that leuteolin can be used as therapy in CM patients, but further research must still be done to see the effectiveness of leuteolin in the treatment of malaria, especially CM.

\section{BETULINIC ACID}

Betulinic acid ((3ß)-3-Hydroxy-lup-20(29)-en-28-oic acid) is a naturally occurring pentacyclic triterpenoid found in the skin of several plant species, especially white birch (Betula pubescens).$^{73}$ Betulinic acid has been shown to have several pharmacological activities such as antidiabetic, anti-dyslipidemia, anti-inflammatory, antiviral, anticancer, parasiticidal and anti-infectious. ${ }^{74}$ In addition, this compound was also reported to have antimalarial activity against $P$. falciparum strain K1 (chloroquine-resistant) and P. falciparum strain T9-96 (chloroquine-sensitive) with $\mathrm{IC}_{50}$ of $19.6 \mathrm{mg} / \mathrm{ml}$ and $25.9 \mathrm{mg} / \mathrm{ml}$, respectively. ${ }^{75}$ This is in accordance with the results of research by Silva et al., who reported that active betulinic acid inhibits the growth of $P$. falciparum strain 3D7 (chloroquine-sensitive) with $\mathrm{IC}_{50}$ of $18 \pm 0.17$ $\mu \mathrm{M} .{ }^{76}$ Antimalarial activity of betulinic acid is thought to be caused by its ability to bind the PfATP6 protein and sarco/endoplasmic reticulum $\mathrm{Ca}^{2+}$ ATPase (SERCA) in mammals so that it interferes with selectivity between parasites and hosts. ${ }^{77}$ The development of betulinic acid as an antimalarial for the future is very necessary, given that the antimalarial mechanism of this compound is similar to the drug artemisinin by inhibiting the sarco/endoplasmic reticulum $\mathrm{Ca}^{2+}$ ATPase (SERCA) ortholog PfATP6 in P. falciparum, where PfATP6 is the only SERCA type $\mathrm{Ca}^{2+}$ ATPase sequence in the parasitic genome. ${ }^{78-79}$

\section{CONCLUSION}

All of these isolates have been scientifically proven to have antimalarial activity, where each compound has a different mechanism of action in inhibiting the growth of malaria parasites. However, further research must be done to see the effectiveness of these compounds as antimalarials, so that they can be used in the latest malaria treatment, which has now shown resistance to first-line malaria treatment.

\section{ACKNOWLEDGMENT}

This article was funded by the Ministry of Research, Technology and Higher Education of the Republic of Indonesia through Doctoral Dissertation Research No. B/112/E3/RA.00/2021.

\section{CONFLICTS OF INTEREST}

The authors declare that there is no conflict of interest regarding the publication of this article.

\section{ABBREVIATIONS}

SERCA: sarco/endoplasmic reticulum $\mathrm{Ca}^{2+} \mathrm{ATPase}$ CM: cerebral malaria; IL-6: interleukin-6; TNF: tumor necrosis factor; IL-12p40: interleukin-12p40; PBMC: peripheral blood mononuclear cell; VCAM-1: vascular cell adhesion molecule 1; ICAM-1: intercellular adhesion molecule 1; ROS: reactive oxygen species; GSK3 $\beta$ : glycogen synthase kinase-3 $\beta$; PfGSK3 $\beta$ : Plasmodium falciparum glycogen synthase kinase-3 $\beta$; Pfmrp1: $P$. falciparum multidrug resistance protein 1; Pfmdr1: $P$. falciparum multidrug resistance gene 1; Pfcrt: $P$. falciparum chloroquine resistance transporter; NF-kB: nuclear factorkappaB; GSH: glutathione; TrxR: thioredoxin reductase enzyme; LPS: lipopolysaccharide; MAPK: mitogen-activated protein kinase; ERK: extracellular signal-regulated kinases; JNK: c-Jun N-terminal kinases; Hb: haemoglobin; FP IX: ferroprotoporphyrin IX (Heme); GSH: glutathione; SOD: superoxide dismutase; NPP: new permeation pathway; ACP: acyl carrier protein; FabD: malonylCoA-ACP 
transacylase; FabH: $\beta$-ketoacyl-ACP synthase III; FabG: $\beta$-ketoacylACP reductase; FabA or FabZ: $\beta$-hydroxyacyl-ACP dehydratase; FabI: enoyl- ACP reductase; FabB and/or FabF: $\beta$-ketoacyl-ACP synthase I and II; CUR: curcumin; KAEMP: kaempferol; PIR: piperine; ADG: andrographolide; $\boldsymbol{\alpha}$-MG: $\boldsymbol{\alpha}$-mangostin; CAT: catechin; LUT: luteolin; BA: betulinic acid.

\section{REFERENCES}

1. WHO. World Malaria Report 2020. World Health Organization 2020. [cited 2021 Jun 17]. Available from: https://www.mmv.org/ newsroom/publications/world-malaria-report-2020?gclid=EAlalQob ChMlz6ycsoOn7AIVmiQrCh1wPAw0EAAYAiAAEgKcEfD_BwE

2. Utami WS, Nuri, Armiyanti Y. Effect Tithonia diversifolia (Hemsley) A. Gray) ethanol extract as antimalarial on mice strain Balb/c before and after infected by Plasmodium berghei. J Med Plant. 2012;1(5):56-66

3. Burke E, Deasy J, Hasson R, McCormack R, Randhawa, V, Walsh, P. Antimalarial drug from nature. J Trinity Student Med. 2003:1-8.

4. Mustofa. Molekul antimalaria alami: potensi dan tantangan pengembangannya sebagai obat baru untuk malaria. Trad Med J. 2003;8(26):8-18

5. Da'l M, Fajria A, Utami W. Sintesis senyawa analog kurkumin 3,5-BIS-(4'-hidroksi-3'-metoksi-benzilidin)-4-piperidin (monohidrat hidroklorida) dengan katalis HCl. Pharmacon. 2010;11(1):33-8.

6. Chainani-Wu N. Safety and anti-inflammatory activity of curcumin: a component of tumeric (Curcuma longa). J Altern Complement Med. 2003;9(1):161-68.

7. Edwards RL, Luis $\mathrm{PB}$, Varuzza1 PV, Joseph Al, Presley $\mathrm{SH}$ Chaturvedi $R$, et al. The anti-inflammatory activity of curcumin is mediated by its oxidative metabolites. J Biol Chem. 2017;292(52):122.

8. Ak T, Gulcin I. Antioxidant and radical scavenging properties of curcumin. Chem Biol Interact. 2008;174:27-37.

9. Allegra A, Innao V, Russo S, Gerace D, Alonci A, Musolino C. Anticancer activity of curcumin and its analogues: preclinical and clinical studies. Cancer Invest. 2016;35(1):1-22.

10. Dong-Chan K, Sae-Kwang K, Jong-Sup B. Anticoagulant activities of curcumin and its derivative. BMB Rep. 2012;45(4):221-26.

11. Samuhasaneeto $S$, Thong-Ngam D, Kulaputana O, Suyasunanont D, Klaikeaw N. Curcumin decreased oxidative stress, inhibited NF$\mathrm{KB}$ activation, and improved liver pathology in ethanol-induced liver injury in rats. J Biomed Biotechnol. 2009:1-8.

12. Akbik D, Ghadiri M, Chrzanowski W, Rohanizadeh R. Curcuminas a wound healing agent. Life Sci. 2014;116(1):1-7.

13. Reddy RC, Vatsala PG, Keshamouni VG, Padmanaban G, Rangarajan P. Curcumin for malaria therapy. Biochem Biophys Res Commun. 2005;326:472-74

14. Cui L, Miao J. Cytotoxic effect of curcumin on malaria parasite Plasmodium falciparum: inhibition of histone acetylation and generation of reactive oxygen species. Antimicrob Agents Chemother. 2007;51:488-94.

15. Ji HF, Shen L. Interactions of curcumin with the PfATP6 model and the implications for its antimalarial mechanism. Bioorg Med Chem Lett. 2009;19:2453-55.

16. Dohutia C, Chetia D, Gogoi K, Bhattacharyya DR, Sarma K. Molecular docking, synthesis and in vitro antimalarial evaluation of certain novel curcumin analogues. Braz J Pharm Sci. 2017;53(4):114.

17. Waknine-Grinberg JH, McQuillan JA, Hunt N, Ginsburg H, Golenser $J$. Modulation of cerebral malaria by fasudil and other immunemodifying compounds. Exp Parasitol. 2010;125:141-6.
18. Mimche P, Taramelli D, Vivas $L$. The plant-based immunomodulator curcumin as a potential candidate for the development of an adjunctive therapy for cerebral malaria. Malar J. 2011;10(1):1-9.

19. Zhang L, Gu ZL, Qin ZH, Liang ZQ. Effect of curcumin on the adhesion of platelets to brain microvascular endothelial cells in vitro. Acta Pharmacol Sin. 2008;29:800-7

20. Faille D, El-Assaad F, Alessi MC, Fusai T, Combes V, Grau GE. Platelet-endothelial cell interactions in cerebral malaria: the end of a cordial understanding. Thromb Haemost. 2009;102:1093-102.

21. Calderón-Montaño JM, Burgos-Morón E, Pérez-Guerrero $\mathrm{C}$, LópezLázaro MA. Review on the dietary flavonoid kaempferol. Min Rev Med Chem. 2011;11(4):298-344.

22. Holland T, Agarwal P, Wang Y, Leurgans SE, Bennett DA, Booth SL, et al. Dietary flavonols and risk of alzheimer dementia. Neurology. 2020;94(16):1-8

23. Wallqvist A, Fang $X$, Tewari SG, Ye P, Reifman J. Metabolic host responses to malarial infection during the intraerythrocytic developmental cycle. BMC Syst Biol. 2016;10(1):1-18

24. Omoregie ES, Pal A. Antiplasmodial, antioxidant and immunomodulatory activities of ethanol extract of Vernonia amygdalina del. leaf in swiss mice. Avicenna $\mathrm{J}$ Phytomed. 2016;6(2):236-47.

25. Tripathy S, Roy S. Redox sensing and signaling by malaria parasite in vertebrate host. J Basic Microbiol. 2015;55(9):1053-63.

26. Pan $W H, X u X Y$, Shi N, Tsang SW, Zhang HJ. Antimalarial activity of plant metabolites. Int J Mol Sci. 2018;19(1382):1-40.

27. Wang $H$, Kumar A, Lamont RJ, Scott D. GSK3-beta and the contro of infectious bacterial diseases. Trends Microbiol. 2014;22(4):208-17.

28. Wong SK, Jann MLS, Sudi S, Hassan WRM, Chin LP, Embi N, et al. Antimalarial and antiinflammatory effects of Gynura procumbens are mediated by kaempferol via inhibition of glycogen synthase kinase-3 $\beta$ (GSK3 $\beta$ ). Sains Malaysiana. 2015;44(10):1489-500.

29. Droucheau E, Primot A, Thomas V, Mattei D, Knockaert $M$, Richardson $\mathrm{C}$, et al. Plasmodium falciparum glycogen synthase kinase-3: molecular model, expression, intracellular localisation and selective inhibitors. Biochim Biophys Acta. 2004;1697(1-2):181-96.

30. Somsak V, Damkaew A, Onrak P. Antimalarial activity of kaempferol and its combination with chloroquine in Plasmodium berghei infection in mice. J Pathog. 2018:1-7.

31. Barliana MI, Suradji E, Abdulah R. Antiplasmodial properties of kaempferol-3-o-rhamnoside isolated from the leaves of Schima wallichii against chloroquine-resistant Plasmodium falciparum. Biomed Rep. 2014;2(4):579-83.

32. Thiengsusuk A, Muhamad P, Chaijaroenkul W, Na-Bangchang K. Antimalarial activity of piperine. J Trop Med. 2018:1-7.

33. Sabina EP, Nasreen A, Vedi M, Rasool M. Analgesic, antipyretic and ulcerogenic effects of piperine: an active ingredient of pepper. J Pharm Sci Res. 2013;5(10):203-06.

34. Mittal R, Gupta R. In vitro Antioxidant activity of piperine. Methods Find Exp Clin Pharmacol. 2000;22(5):271-74.

35. Tharmalingam N, Kim SH, Park M, Woo HJ, Kim HW, Yang JY, et al. Inhibitory effect of piperine on Helicobacter pylori growth and adhesion to gastric adenocarcinoma cells. Infect Agents Cancer. 2014;9(43):1-10

36. Lee SA, Hong SS, Han XH, Hwang JS, Oh GJ, Lee KS, et al. Piperine from the fruits of Piper longum with inhibitory effect on monoamine oxidase and antidepressant-like activity. Chem Pharm Bull. 2005;53(7):832-35.

37. Nirwane AM, Bapat A. Effect of methanolic extract of Piper nigrum fruits in ethanol-CCl4 induced hepatotoxicity in wistar rats. Der Pharma Lettre. 2012;4(3):795-802. 
38. Kim SH, Lee YC. Piperine inhibits eosinophil infiltration and airway hyperresponsiveness by suppressing $\mathrm{T}$ cell activity and Th2 cytokine production in the ovalbumin-induced asthma model. J Pharm Pharmacol. 2009;61:353-59.

39. Bang JS, Choi HM, Sur BJ, Lim SJ, Kim JY, Yang HI, et al. Antiinflammatory and antiarthritic effects of piperine in human interleukin $1 \beta$-stimulated fibroblast-like synoviocytes and in rat arthritis models. Arthritis Res Ther. 2009;11(2):1-9.

40. Bukhari IA, Alhumayyd MS, Mahesar AL, Gilani AH. The analgesic and anticonvulsant effects of piperine in mice. J Physiol Pharmacol. 2013;64(6):789-94.

41. Antony HA, Parija S. Antimalarial drug resistance: an overview. Trop Parasitol. 2016;6(1):30-41.

42. Rijpma SR, Van Der Velden M, Bilosetal A. MRP1 mediates folate transport and antifolate sensitivity in Plasmodium falciparum. FEBS Lett. 2016;590(4):482-92.

43. Huang B, Wang Q, Dengetal C. Prevalence of crt and mdr-1 mutations in Plasmodium falciparum isolates from grande comore island after withdrawal of chloroquine. Malar J. 2016;15(1):1-9.

44. Martin RE, Kirk, K. The malaria parasite's chloroquine resistance transporter is a member of the drug/metabolite transporter superfamily. Mol Bio Evol. 2004;21(10):1938-49

45. Jayakumar T, Hsieh CY, Lee JJ, Sheu J. Experimental and clinical pharmacology of Andrographis paniculata and its major bioactive phytoconstituent andrographolide. Evid based Compl Alternat Med. 2013:1-16.

46. Jarukamjorn K, Nemoto N. Pharmacological aspects of Andrographis paniculata on health and its major diterpenoid constituent andrographolide. J Health Sci. 2008;54(4):370-81.

47. Mishra K, Dash AP, Dey NA. Andrographolide: a novel antimalarial diterpene lactone compound from Andrographis paniculata and its interaction with curcumin and artesunate. J Trop Med. 2011:1-6.

48. Tripathi AK, Sha W, Shulaev V, Stins MF, Sullivan Jr D. Plasmodium falciparum-infected erythrocytes induce NFKB regulated inflammatory pathways in human cerebral endothelium. Blood. 2009;114(19):4243-52.

49. Bao Z, Guan S, Cheng C, Wu S, Wong SH, Kemeny DM, et al. A novel antiinflammatory role for andrographolide in asthma via inhibition of the nuclear factor- $\kappa b$ pathway. Am J Respir Crit Care Med. 2009;179(8):657-65.

50. Risdawati. The mechanism of action of andrographolide a compound of sambiloto (Andrographis paniculata Nees.) as an antimalarial drug study on oxidative stress of Plasmodium berghei ANKA. Disertasi, Program Doktoral. Depok: Universitas Indonesia; 2014.

51. Kusumawardhani D, Widyawaruyanti A, Kusumawati I. Efek antimalaria ekstrak sambiloto terstandar (parameter kadar andrografolida) pada mencit terinfeksi Plasmodium berghei. Airlangga J Pharm. 2005;5(1):25-9.

52. Sachdeva M. Analysis of in vitro antimalarial activity of andrographolide and 5-hydroxy-7,8-dimethoxyflavone isolated from Andrographis paniculata against Plasmodium berghei parasite. Pharm Sci Monitor. 2011:2(4):104-16.

53. Mahabusarakam W, Kuaha K, Wilairat P, Taylor W. Prenylated xanthones as potential antiplasmodial substances. Planta Med. 2006:72(10):912-16

54. Ibrahim MY, Hashim NM, Mariod AA, Mohan S, Abdulla MA, Abdelwahab SI, et al. a-mangostin from Garcinia mangostana Linn: an updated review of its pharmacological properties. Arabian J Chem. 2016:9:317-29.

55. Ignatushchenko MV, Winter RW, Baechinger HP, Hinrichs DJ, Riscoe M. Xanthones as antimalarial agents: studies of a possible mode of action. FEBS Lett. 1997;409:67-73.
56. Riscoe M, Kelly JX, Winter R. Xanthones as Antimalarial agents: discovery, mode of action and optimization. Curr Med Chem. 2005;12:2539-49.

57. Kelly JX, Winter R, Peyton DH, Hinrichs DJ, Riscoe M Optimization of xanthones for antimalarial activity: the 3,6-bis-هdiethylaminoalkoxyxanthone series. Antimicrob Agents Chemother. 2002;46:144-50.

58. Kuncoro $\mathrm{H}$, Widyawaruyanti $\mathrm{A}$, Ersam T. a-mangostin effect on inhibition development stadium and globin accumulation against Plasmodium falciparum. Pharmacog J. 2018;10(4):783-88.

59. Upegui $Y$, Robledo SM, Romero JFG, Quiñones W, Archbold R, Torres $F$, et al. In vivo antimalarial activity of a-mangostin and the new xanthone $\delta$-mangostin. Phytother Res. 2015;29(8):1195-201.

60. Sen G, Sarkar N, Nath M, Maity S. Bioactive components of tea. Arch Food Nutr Sci. 2020;4:001-09.

61. Bae J, Kim N, Shin Y, Kim SY, Kim Y. Activity of catechins and their applications. Biomed Dermatol. 2020;4(8):1-10.

62. Budiman I, Tjokropranoto R, Widowati W, Rahardja F, Maesaroh M Fauziah N. Antioxidant and anti-malarial properties of catechins. $\mathrm{Br}$ J Med Med Res. 2015;5(7):895-902.

63. Abdulah R, Suradji EW, Subarnas A, Supratman U, Sugijanto M Diantini $A$, et al. Catechin isolated from Garcinia celebica leaves inhibit Plasmodium falciparum growth through the induction of oxidative stress. Pharmacogn Mag. 2017;13(2):301-5.

64. Goyal M, Alam A, Bandyopadhyay U. Redox regulation in malaria: current concepts and pharmacotherapeutic implications. Curr Med Chem. 2012;19:1475-503

65. Mohring F, Pretzel J, Jortzik E, Becker K. The redox systems of Plasmodium falciparum and Plasmodium vivax: comparison, in silico analysis and inhibitor studies. Curr Med Chem. 2014;21:1728-56.

66. Lin $Y$, Shi $R$, Wang $X$, Shen $H$. Luteolin, a flavonoid with potentials for cancer prevention and therapy. Curr Cancer Drug Targets. 2008;8(7):634-46.

67. Dong H, Yang $X$, He J, Cai S, Xiao K, Zhu L. Enhanced antioxidant activity, antibacterial activity and hypoglycemic effect of luteolin by complexation with manganese (II) and its inhibition kinetics on xanthine oxidase. RSC Adv. 2017;7:53385-95.

68. Lehane AM, Saliba K. Common dietary flavonoids inhibit the growth of the intraerythrocytic malaria parasite. BMC Res Notes. 2008; $1(26): 1-5$

69. Deniz T, Gabriela L, Reto B, Peter R, Leonardo S, Remo P. Inhibition of Plasmodium falciparum fatty acid biosynthesis: evaluation of FabG, FabZ, and Fabl as drug targets for flavonoids. J Med Chem. 2006;49:3345-53.

70. Chen CY, Peng WH, Tsai KD, Hsu S. Luteolin suppresses inflammation-associated gene expression by blocking NF-kappaB and AP-1 activation pathway in mouse alveolar macrophages. Life Sci. 2007;81:1602-14

71. Xagorari A, Roussos C, Papapetropoulos A. Inhibition of LPS stimulated pathways in macrophages by the flavonoid luteolin. $\mathrm{Br} \mathrm{J}$ Pharmacol. 2002;136:1058-64.

72. Karin M. Mitogen activated protein kinases as targets for development of novel anti-inflammatory drugs. Ann Rheum Dis. 2004:63(2):62-4.

73. Tan Y, Yu R, Pezzuto JM. Betulinic acid-induced programmed cell death in human melanoma cells involves mitogen-activated protein kinase activation. Clin Cancer Res. 2003:9(7):2866-75.

74. Ríos J, Máñez S. New pharmacological opportunities for betulinic acid. Planta Med. 2018;84(01):8-19.

75. Steele JCP, Warhurst DC, Kirby GC, Simmonds MS. In vitro and in vivo evaluation of betulinic acid as an antimalarial. Phytother Res. $1999: 13: 115-19$ 
76. Silva GNS, Maria NRG, Schuck DC, Cruz LN, de Moraes MS, Nakabashi $M$, et al. Two series of new semisynthetic triterpene derivatives: differences in anti-malarial activity, cytotoxicity and mechanism of action. Malar J. 2013;12(89):1-7.

77. Diedrich D, Wildner AC, Silveira TF, Silva GNS, Santos Fd, do Canto $V P$, et al. SERCA plays a crucial role in the toxicity of a betulinic acid derivative with potential antimalarial activity. Chem-Biol Interact. 2018;287:70-7.
78. Eckstein-Ludwig U, Webb RJ, van Goethem IDA, East JM, Lee AG, Kimura M, et al. Artemisinins target the SERCA of Plasmodium falciparum. Nature. 2003;424:957-61.

79. Jung $\mathrm{M}$, Kim H, Nam KY, No K. Three-dimensional structure of Plasmodium falciparum $\mathrm{Ca}^{2+}$ ATPase (PfATP6) and docking of artemisinin derivatives to PfATP6. Bioorg Med Chem Lett. 2005:15(12):2994-97.

\section{GRAPHICAL ABSTRACT}<smiles>COc1cc(/C=C/C(=O)CC(=O)/C=C/c2ccc(O)c(OC)c2)ccc1O</smiles>

Curcumin<smiles>O=C(/C=C/C=C/c1ccc2c(c1)OCO2)N1CCCCC1</smiles>

\section{Piperine}<smiles>COc1c(O)cc2oc3cc(O)c(CC=C(C)C)c(O)c3c(=O)c2c1CC=C(C)C</smiles>

$\alpha$-Mangostin<smiles>O=c1cc(-c2ccc(O)c(O)c2)oc2cc(O)cc(O)c12</smiles>

Luteolin<smiles>O=c1c(O)c(-c2ccc(O)cc2)oc2cc(O)cc(O)c12</smiles>

Kaempferol

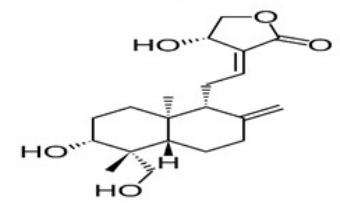

\section{Andrographolide}<smiles>Oc1cc(O)c2c(c1)O[C@H](c1ccc(O)c(O)c1)[C@H](O)C2</smiles>

Catechin

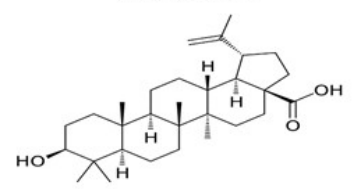

Betulinic acid

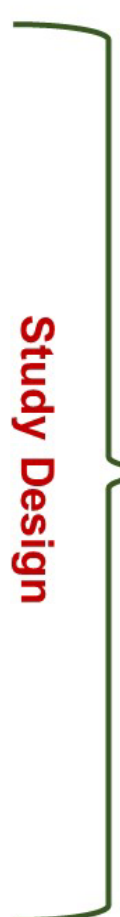

P. falciparum strain 3D7.

P. falciparum strain D10.

$P$. falciparum strain DD2.

P. falciparum strain $7 \mathrm{G} 8$.

$P$. falciparum strain $\mathrm{K} 1$.

P. falciparum strain FCR3.

P. falciparum strain $7 \mathrm{G8}$.

P. falciparum strain T9-96.

In vitro assay
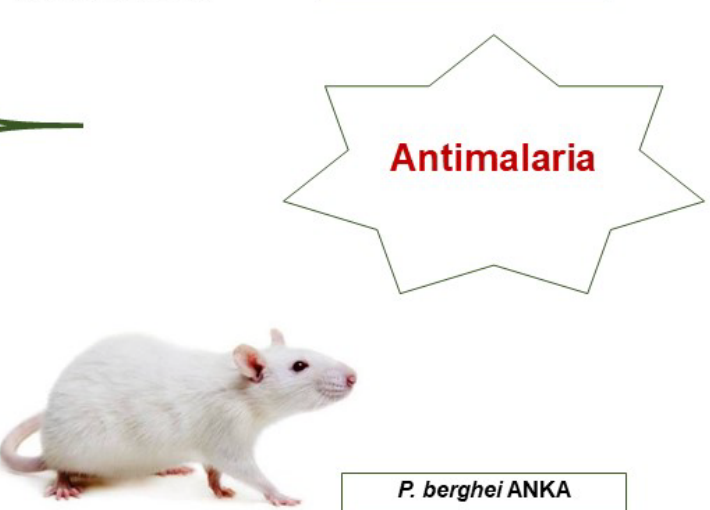

In vivo assay
P. berghei ANKA 


\section{ABOUT AUTHORS}

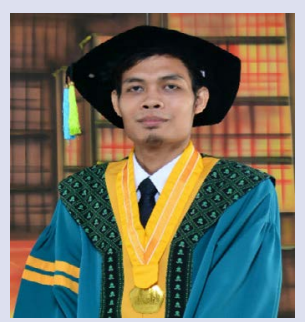

Maulana Yusuf Alkandahri: A Doctoral student at the Department of Pharmacology and Clinical Pharmacy, Faculty of Pharmacy, Padjadjaran University, Indonesia. He is also a lecturer at the Faculty of Pharmacy, Buana Perjuangan Karawang University, Indonesia.

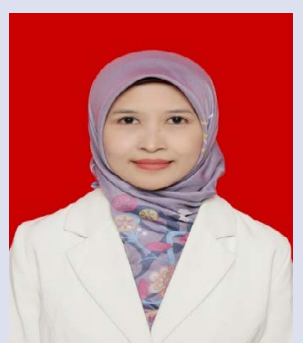

Nia Yuniarsih: A lecturer at the Faculty of Pharmacy, Buana Perjuangan Karawang University, Indonesia.

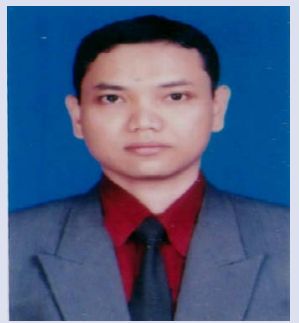

Afiat Berbudi: A lecturer at the Department of Biomedical Sciences, Parasitology Division, Faculty of Medicine, Padjadjaran University, Indonesia.

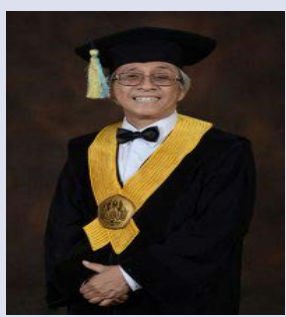

Anas Subarnas: A Professor at the Department of Pharmacology and Clinical Pharmacy, Faculty of Pharmacy, Padjadjaran University, Indonesia.

Cite this article: Alkandahri MY, Yuniarsih N, Berbudi A, Subarnas A. Antimalaria Activities of Several Active Compounds from Medicinal Plants. Pharmacogn J. 2022;14(1): 245-252. 